\title{
Understanding the Critical Aspects of South Asian Labor Market: Implications and Policy Responses
}

Abstract

Objectives: This paper attempts to explore the critical insights into the labor markets of South Asian countries taking ILO's Key Indicators of the Labor Market (KILM) as an example for illustrations. In addition, the paper puts its lens on addressing adequate policies and program responses at country level, especially for Bangladesh.

Methodology: This is basically a policy-focused study focusing on an extensive analysis of existing relevant documents and literature. The paper has therefore adopted three steps methodological approach: collecting, scrutinizing and analyzing. The required data were collected from secondary sources including strategic papers, technical notes, conference proceedings, statistical reports, research articles, relevant books and e-materials of reputed international organizations such as ILO and World Bank.

Findings: A critical review of the existing facts and documents has revealed that despite geo-political and ethnical differences, South Asian labor economies are characterized with homogonous labor market characteristics including low labor force participation rate, gender gap in employment and wages, notable labor dependency ratio, working poor, sluggish wage growth, low labor productivity, excessive working hours, high NEET rate, and a state of labor underutilization. In addition, countries differ in terms of policy issues, implementation levels, data availability and compliance to ILO's decent work agenda to a large extent.

Recommendations: An integrated labor policy incorporating the lessons and experiences of developed countries, opinions of stakeholders and labor specialists, balanced and diversified development programs, compliance to ILO's decent work agenda, and collaborative works with national and international labor organizations are supposed to contribute to better functioning of labor markets.

Implications: Although this region of the world is blessed with abundant labor force, a critical analysis has revealed several implications at both national and regional level. The current scenario of lower labor force participation rate and higher time-related underemployment indicate the absence of policies for the fullest utilization of this golden human resource. In addition, slow or negative wage growth and poor wages badly affect the living standards of workers. Despite the consecutive growth in industry and service sector, still the employment in this region is predominantly agricultural which in turn is largely responsible for informal employment.

Value/Originality: This study is one of very few labor market studies focusing on the critical aspects of South Asian labor markets. The paper is therefore expected to add value to the existing field of regional labor market research. Academics, researchers, policymakers and stakeholders are largely be benefitted from this study.

Keywords: South Asian labor market, employment in South Asia, labor market, labor policy

\section{Introduction}

In the last two decades, the world experienced the impact of global financial crisis at both national and international levels. Almost all the countries disregarding the size of the economy were affected with varying degree due to the fact that 'financial markets are highly integrated at the global level' (Alcidiand Gross, 2010; Daly et al., 2014). This global financial crisis led to the substantive changes in macroeconomic policies resulting in structural labor policy reforms across countries.

Despite a devastating global impact on incomes, government finances and, not the least, labor markets (Leschkeand Watt, 2010), the global economic growth reached at 3.6 per cent in 2017 compared to 3.2 per cent in 2016.

\footnotetext{
${ }^{1}$ Assistant Professor, Department of Management Studies, University of Barisal, E-mail : mamin_83@hotmail.com 
Business Review- A Journal of Business Administration Discipline, Khulna University, Volume: 13, Number: 1E2,January-December 2018, pp.29-45 (Print ISSN : 1811-3788; Online ISSN : 2664-3502)

However, global unemployment remains elevated at more than 190 million (ILO, 2018). In World Employment Social Outlook Trends 2018, ILO reported significant variations in employment outcomes between regions and countries. With notable expansions in developing, emerging and developed countries, the global unemployment rate is supposed to fall to 5.5 per cent in 2018 (from 5.6 per cent in 2017) (ILO, 2018). Accordingly, for many developing and emerging economies, aggregate labor market and social trends are supposed to be characterized with demographic disparities like age and gender gap. Unlike other economic regions in the world, South Asia is tracked with a higher rate of employment growth comprising near about 40 per cent of the world's working-age (15-64) population (World Bank, 2011). The robust economic growth, near about 6 per cent over the last decade, is associated with an increase in real wages and job quality (Shamsuddin, 2013; World Bank, 2011). Nonetheless, it is also home to more than 40 per cent of the world's absolute poor. Although nearly 1.0-1.2 million new workers join the labor force each month in this region, labor markets are confronted with numerous challenges in creating more and better jobs. This ultimately poses pressures to policy makers and development partners to undertake policy reforms in order to ensure better functioning of labor markets. Moreover, the heterogeneity of the countries in this region is evident in terms of quality jobs, economic growth, labor policies, and demographic profiles.

Despite there is an enormous potential of developing a highly skilled workforce in South Asian region, mainly generated from accelerated economic growth and shifts in demographic profiles, very few countries apparently adopted time worthy labor policies addressing the contemporary challenges. Moreover, very few studies were conducted so far on this inevitable economic segment. In addition, the existing literature on South Asian labor markets focused on isolated issues. Research papers focusing on the fundamental aspects of labor market are scarce. This paper therefore attempts to explore the critical aspects of South Asian labor market with a special emphasis on policy implications.

The remainder of this paper consists of five consecutive sections. The paper, at first, sets the rationale and purpose of conducting such a study on regional labor market. The paper then explains the methodological approach used in this research followed by a critical review of contemporary studies. Then, the critical aspects of South Asian labor market are explored taking ILO's Key Indicators of the Labor Market (KILM) into consideration along with their implications. Finally, the paper is concluded with articulating several policy options.

\section{Rationale and Purpose}

This study is critically important for five distinct reasons. First and the foremost important rationale of conducting this study is the concurrent debates and discussions concerning the labor market scenario in South Asian region. Near about 8,00,000 new jobs a month are created in this regional labor market exerting significant influence on macroeconomic performance (World Bank, 2011). The accelerated economic growth since the 1980s, especially in Bangladesh and India, has opened the doors of millions of jobs. However, there has been a notable increase in income and labor market inequalities in several countries of this region (Sharma, 2018). This requires a comprehensive understanding of the facts and patterns of labor market of this region. Accordingly, this paper focuses on the fundamental aspects of labor markets intending to craft a comparative picture of labor markets in South Asian region.

Second, the existing literature concerning employment and labor markets in South Asian region is inadequate. Despite the enormous contribution made by this huge human capital to the economy, labor markets and policy issues have received less attention in literature. Moreover, the existing literature on this subject is diverse (Burchellet al., 2014.) and mainly confined to institutional publications. This study is supposed to fill in this research gap to a large extent. Third, this paper focuses on the implications of existing labor market scenario on the national economies in addition to describing the labor facts. Moreover, several policy options are provided in the paper addressing the need of policy makers, labor market participants, development organizations, research institutes and independent researchers. Fourth, the paper is expected to open the doors for future research at both national and regional level. Last but not least, the paper serves the academic purpose for those involved in labor economics, development studies and the business studies at large.

Considering the above justifications of conducting such a study, this paper is mainly intended to achieve three objectives: (i) to explore the critical insights into the South Asian labor market; (ii) to analyze the subsequent 
Business Review- A Journal of Business Administration Discipline, Khulna University, Volume: 13, Number: 1E2,January-December 2018, pp.29-45 (Print ISSN : 1811-3788; Online ISSN : 2664-3502)

implications of existing labor market indicators at country level; and finally (iii) to provide a set of policy options for policy makers, development partners, and labor market participants.

\section{Methodology}

As noted earlier, this is basically a policy research paper addressing the different aspects of South Asian labor market based on available documents and statistics. Hence, the study is best suited to documentary research. Document research is the use of secondary (outside) sources, mainly documents, to explore the research problem within an academic setting (Prior, 2003). Documents analysis is an effective way of exploring and interpreting the different dimensions of the phenomena under investigation due to manageability, accessibility and reliability. This is largely due to the fact that documents are stable and non-reactive data sources i.e., data can be read and reviewed multiple times and this data remain unchanged throughout the research process (Bowen, 2009). Moreover, in documents review, a researcher treats documents or facts like a respondent or informant that serves the researcher with relevant information (O'Leary, 2014).

In this study, we followed three basic steps of documents research: collecting, scrutinizing and analyzing. Accordingly, the required data were collected from secondary sources. At first, relevant documents such as working papers, strategic dialogues, technical notes, conference proceedings, research articles, statistical publications, relevant books and e-materials were collected. Then, the collected documents and facts were scrutinized in pursuit of the objectives of this study. Finally, we used the scrutinized data for analysis and illustrations. Since reliability is the prime concern in documents review (Scott, 2006), we focused on documents and statistical facts published by reputed organizations such as ILO, World Bank, Asian Development Bank, UNDP, and so on. ILOSTAT, the official website of International Labor Organization (ILO), serves the main source of statistical facts used in this paper. This study uses ILO's Key Indicators of the Lab our Market (KILM) for the purpose of illustrations. However, we confined our discussions to sixteen indicators, as indicated in KILM, and excluded five indicators from consideration due to data unavailability. Since data across countries vary to a large extent, we use the same data with different years for different countries in some cases.

\section{Literature Review}

Literatures pertaining to employment, wages and working conditions have been augmented since the last two decades in response to the effects of global financial recession. Accordingly, labor market issues have received a great deal of public policy and academic attention at both national and international level (Burchell et al., 2014). In addition, the dual process of globalization and liberalization have led to the labor market flexibility across countries resulting in more calls for formal and productive employment, career growth, better working conditions, and social security (Rose, 2003; Gallie et al., 2004;Dexand Bond, 2005; Kalleberg, 2011). In addition, ILO's introduction of decent work agenda in 1999 added fuel to the debates and discussions of labor market functioning, especially in terms of 'quality of employment' (Reineckeand White, 2004; Alli, 2009).

An increase or decrease in labor force participation is not now enough to trace the employments outlook in a given economy. In response to the debates in regard to what actually constitutes a lobar market, ILO introduced Key Indicators of the Labour Market (KILM) in 2015. This KILM now serves a better operational tool to measure the labor market effectiveness and efficiency. As a result, monthly earnings, average wages, working hours, labor productivity and status in employment have received significant importance in exploring a country's labor market (Hall and Soskice, 2001; Gallie, 2007).

Several studies were conducted so far to explore the international comparisons of regional labor markets' reactions to the concurrent economic growth and financial crisis (e.g., Chamberlin, 2011; Schäfer, 2005; Lee, 2000; Moazzami and Dadgostar, 2009). Many studies support the positive relationship between economic growth and labor market development (Oberst, 2012). Herwartz and Niebuhr (2011), for instance, conducted a study to examine the regional impact of unemployment intensity on economic growth. In essence, regional labor markets are dependent to a large extent (Niebuhr, 2003) and this relationship exerts significant influence at both regional and country levels. Thus, understanding the patterns of regional labor market is essentially critical to explore the dynamics of national labor market. Although South Asia experienced 6.5 percent economic growth rate in 2017 
Business Review- A Journal of Business Administration Discipline, Khulna University, Volume: 13, Number: 1E2,January-December 2018, pp.29-45 (Print ISSN : 1811-3788; Online ISSN : 2664-3502)

(compared to 6.7 percent in 2016) and it is expected to pick up at 7.0 per cent in 2019, very few studies focused on this regional labor market.

Several studies explored this regional labor markets from multiple perspectives (e.g., Ramaswamy, 2003; World Bank, 2011; Kim andBhardwaj, 2011; Srivastava and Pandey, 2017). Sharma (2017) studied South Asian labor market and employment patterns from economic growth perspectives and found that most of the South Asian workers have low-paying jobs with little or no job protection. Thus, rapid economic growth in this region fails to create better jobs for its fast growing labor force. Doherty et al. (2014) examined the causes behind the labor migration from South Asia to other countries taking four countries into consideration (India, Bangladesh, Sri Lanka, and Nepal). The study revealed that working poverty and unemployment along with attractive opportunities for higher earnings abroad are largely responsible for unprecedented levels of migration from South Asia to rest of the World. In a recent study, Chand (2018) investigated the impact of rapidly aging populations in South Asia and concluded that there are several severe implications of this rapidly growing aging population for labor market functioning including rising costs for pensions and healthcare, higher dependency ratios, and changing family dynamics.

Notably, most of the existing studies on South Asian labor markets focused on the isolated issues of labor market and employment dynamics. In addition, most of these studies were conducted at the institutional level, such as ILO, World Bank, ADB and so on. The absence of research papers focusing on the dynamics of South Asian regional labor market is highly evident in literature.

This paper attempts to explore the critical insights into South Asian labor markets taking ILO's KILM into consideration. The paper is therefore supposed to fill in the research gap to a large extent.

\section{Discussion}

In this section of the paper, we first define the term 'South Asia' and the scope of South Asian labor market along with a brief analysis of development scenario of South Asian economies. Then, the state of labor markets of South Asian countries are explored taking ILO's Key Indicators of the Lab our Market (KILM) into consideration for illustrations. Each indicator of labor market, as prescribed in KILM, is first conceptually described in this paper followed by critical analysis of South Asian labor market with statistical facts. The implications of existing labor market scenario, at national and regional levels, are briefly discussed throughout this section.

South Asia, also known as Southern Asia, is the southern region of Asian Continent. Although there is a controversy in regard to which countries are actually included in South Asia (Mann, 2014), modern definitions of South Asia include eight countries including Afghanistan, India, Pakistan, Bangladesh, Sri Lanka, Nepal, Bhutan and Maldives (World Bank, 2015). Notably, controversy mainly arises about Afghanistan and Myanmar (Razzaque, 2004)). However, for better illustration in this paper, we focus on eight current territories listed in the South Asian Association for Regional Cooperation (SAARC). Accordingly, the scope of South Asian labor market is confined to the labor markets of these eight countries i.e. Afghanistan, India, Pakistan, Bangladesh, Sri Lanka, Nepal, Bhutan and Maldives.

With a projected economic growth rate of 7.1 per cent in 2018, South Asia has emerged as the one of the fastest economic regions in the world (World Bank, 2011). The consistent and strong economic performance, an increase in GDP growth from 6.2 per cent to 7.5 per cent between 2013 and 2016, has made South Asia as an integrated economic powerhouse. In addition, this region has been less vulnerable to global financial turmoil (Seth, 2018). This accelerated economic growth has opened the untapped employment potentials for 1.891 billion people of this region which comprises about one fourth of the world's population. Among this population, 40 per cent are in working age group (15-64 years). According to World Bank (2018), an estimated 1.0 - 1.2 million people enter the labor market per month in this region. Thus, economic growth followed by productive employment is supposed to contribute to human development in this emerging economic region to a large extent. 
Business Review- A Journal of Business Administration Discipline, Khulna University, Volume: 13, Number: 1E2,January-December 2018, pp.29-45 (Print ISSN : 1811-3788; Online ISSN : 2664-3502)

Table 1: Basic Development Indicators

\begin{tabular}{|c|c|c|c|c|c|c|c|}
\hline \multirow[t]{2}{*}{ Country } & \multirow[t]{2}{*}{$\begin{array}{l}\text { Populations } \\
\text { (In Millions) } \\
(2017)\end{array}$} & \multirow{2}{*}{$\begin{array}{l}\text { Working Age } \\
\text { Population (15- } \\
64)(\% \text { of total) } \\
\text { (2016) }\end{array}$} & \multirow{2}{*}{$\begin{array}{l}\text { GNI Per } \\
\text { Capita } \\
\text { (in } \\
\text { US\$)(2017) }\end{array}$} & \multirow{2}{*}{$\begin{array}{l}\text { GDP } \\
\text { Growth } \\
\text { Rate } \\
(2017)\end{array}$} & \multirow{2}{*}{$\begin{array}{l}\text { Gender } \\
\text { Parity } \\
\text { Index } \\
\text { (GPI) } \\
(2017) \\
\end{array}$} & \multicolumn{2}{|c|}{$\begin{array}{l}\text { Human } \\
\text { Development Index } \\
\text { (2018) }\end{array}$} \\
\hline & & & & & & Value & Rank \\
\hline Afghanistan & 35.53 & 54.17 & 570 & 2.6 & 1 & 0.498 & 168 \\
\hline Bangladesh & 164.67 & 66.53 & 1470 & 7.3 & 1 & 0.608 & 136 \\
\hline Bhutan & 0.81 & 68.57 & 2720 & 6.8 & 1 & 0.612 & 134 \\
\hline India & 1339.18 & 66.23 & 1820 & 6.6 & 1 & 0.640 & 130 \\
\hline Maldives & 0.44 & 72.47 & 9570 & 8.8 & 1 & 0.717 & 101 \\
\hline Nepal & 29.30 & 63.30 & 790 & 7.5 & 1 & 0.574 & 149 \\
\hline Pakistan & 197.02 & 60.73 & 1580 & 5.7 & 1 & 0.562 & 150 \\
\hline Sri Lanka & 21.44 & 65.92 & 3840 & 3.1 & 1 & 0.770 & 76 \\
\hline
\end{tabular}

Note: Figures in italics refer to periods other than those specified.

Source: World Development Indicator Database (2018) \& Human Development Report 2018

As noted in table I, GDP growth rates among the South Asian countries look sound as compared to many other developing economies in the world. Maldives achieved the highest GDP growth (8.8 per cent) followed by Nepal (7.5 per cent) and Bangladesh (7.3 per cent). Accordingly, the per capita income is the highest in Maldives $(9,570$ US\$) in this region. In spite of being the biggest country in South Asia, India's growth rate was 6.6 per cent in 2017. Sri Lanka and Afghanistan are at the bottom of the table of GDP growth rate comprising 3.1 per cent and 2.6 per cent respectively. Afghanistan has been struggling for economic recovery since last few years, but the pace is slow as continued insecurity is curtailing private investment and consumer demand (World Bank, 2018).

Afghanistan's biggest challenge is now to find out the sustainable sources of growth. Although the GDP growth rate of Sri Lanka is lower than most of the countries in South Asia, its per capita income is better than those of other countries except Maldives. In addition, this country (Sri Lanka) is in the better position in terms of human development index [see table I]. Although Sri Lanka is estimated to reach 4 per cent GDP growth rate in 2018, this economy is supposed to remain vulnerable because of sizable public debt, large refinancing needs, and low external buffers (IMF, 2018).

Despite the differences in economic growth across countries, this region is blessed with abundant working age population exerting significant potential to economic growth. Almost all the countries of this region have above 60 per cent working age population except Afghanistan (54.17 per cent). Thus, South Asian countries are in an advantageous position to avail demographic dividend opportunities.

\section{Labor Force Participation Rate}

Theoretically, the labor force participation rate (LFPR) refers to the number of people available for work in a given economy as a percentage of the total population. However, people who are still undergoing studies, housewives, incapable adults, and persons above the age of 64 are not included in labor force. In economics and development studies, LFPR is critical to understand the overall employment status in the economy. In terms of labor force participation, Nepal is in better position than other countries with 84.21 per cent followed by Bhutan (66.79 per cent) and Maldives (65.83 per cent). Table II presents the trends in labor force participation rates in South Asian countries. India and Sri Lanka experienced a downward trend in labor force participation between 1990 and 2017. This implies slow progress in economic activities in these countries between these periods which resulted in fewer jobs. Moreover, it discouraged the people to focus on employment.

Table 2: Labor Force Participation Rate

\begin{tabular}{|l|r|r|r|r|r|}
\hline Country & 1990 & 2017 & Country & 1990 & 2017 \\
\hline Afghanistan & 51.39 & 54.24 & Maldives & 49.47 & 65.83 \\
\hline Bangladesh & 56.48 & 56.50 & Nepal & 85.41 & 84.21 \\
\hline
\end{tabular}


Business Review- A Journal of Business Administration Discipline, Khulna University, Volume: 13, Number: 1E2,January-December 2018, pp.29-45 (Print ISSN : 1811-3788; Online ISSN : 2664-3502)

\begin{tabular}{|l|r|r|r|r|r|}
\hline Bhutan & 64.46 & 66.79 & Pakistan & 50.73 & 54.44 \\
\hline India & 60.66 & 53.79 & Sri Lanka & 62.51 & 53.54 \\
\hline
\end{tabular}

Source: World Bank, 2018

Whatever the case, a downward trend in these countries is a negative sign for economies as near about half of the population is outside the labor force. However, the rest of the countries remain constant in this regard. The labor force participation rate was increased from 49.47 per cent in 1990 to 65.83 per cent in 2017 in Maldives indicating the sound prospect of the economy as well as a better labor market. In essence, a higher LFPR contributes to labor market through the adequate labor supply. At the same time, government, policy makers and employers must create productive employment opportunities for the growing participants of the labor market.

\section{Employment-to-Population Ratio}

In highlighting the importance of employment-to-population ratio (EPR) as an indicator in labor economics, the Organization for Economic Co-operation and Development (OECD) considers the employment-to-population ratio as the employment rate in a given economy. In essence, EPR indicates the ratio of working age (15-64 years) populations who are currently employed. However, there are concurrent debates and discussions in regard to what actually constitutes EPR.

The United States Census Bureau, for example, includes those people in calculating EPR that have stopped looking for work. ILO considers a person as employed if he or she has 'worked for at least one hour for pay or profit in the short reference period' (ILO, 2019).

Table 3: Employment-to-Population Ratio

\begin{tabular}{|l|r|r|r|l|r|r|r|}
\hline Country & Male & Female & Total & Country & Male & Female & Total \\
\hline Afghanistan & 77.1 & 16.9 & 48 & Maldives & 80.1 & 54.8 & 67.5 \\
\hline Bangladesh & 78.2 & 41.1 & 59.7 & Nepal & 83.7 & 77.5 & 80.4 \\
\hline Bhutan & 71.8 & 57.8 & 65.4 & Pakistan & 78.7 & 22.2 & 51.1 \\
\hline India & 76.4 & 25.9 & 51.9 & Sri Lanka & 72.2 & 28 & 49.1 \\
\hline
\end{tabular}

As noted in table III, the employment-to-population ratio is the highest in Nepal (80.4 per cent) indicating a large proportion of this country's population is employed. The ratio is moderate in Bangladesh (59.7 per cent), Bhutan (65.4 per cent), and Maldives (67.5 per cent). In India, Pakistan, and Sri Lanka, the ratios are 51.9, 51.1 and 49.1 per cent respectively that indicates the absence of participation of large share of population in labor market. The basic implication is that near about half of the population of these three countries including Afghanistan is not directly involved in labor market activities. They are either unemployed or at least out of the labor force altogether. Moreover, gender disparity is observed in employment ratio among all South Asian countries. Being an economic leader in this region, the EPR in India between male and female is 76.4 per cent and 25.9 per cent respectively. The case is more deteriorating in Afghanistan, Pakistan and Sri Lanka. The gender gap in employment has been reduced at a remarkable rate in Bangladesh due to females' higher involvement in readymade garments (RMG) sector in last few decades. Thus, actions of South Asian governments and respective stakeholders are required to incorporate more females into employment.

\section{Labor Dependency Ratio}

In labor economics, labor dependency ratio is used to measure the productive part of a country's population. Thus, labor dependency is basically the age-population ratio that indicates the ratio between those who are in the labor force (15-64 years) and those who are not in the labor forces (0-14 \& 65+). Thus, dependent part of the economy comprises people with ages 0 to 14 and 65+. From labor market perspective, dependency ratio is critically important as it provides an overview to track shifts in the population. This ratio is sometimes criticized on the ground that some people may tend to work beyond 65 years and, in some countries, people below 14 years may chose to work for survival. Nonetheless, labor dependency ratio helps to measure pressure on productive population. 
Business Review- A Journal of Business Administration Discipline, Khulna University, Volume: 13, Number: 1E2,January-December 2018, pp.29-45 (Print ISSN : 1811-3788; Online ISSN : 2664-3502)

Table 4: Labor Dependency Ratio

\begin{tabular}{|l|r|l|r|}
\hline Country & Labor Dependency Ratio & Country & Labor Dependency Ratio \\
\hline Afghanistan & 2.67 & Maldives & 0.94 \\
\hline Bangladesh & 1.34 & Nepal & 0.8 \\
\hline Bhutan & 1.08 & Pakistan & 2 \\
\hline India & 1.67 & Sri Lanka & 1.68 \\
\hline
\end{tabular}

Source: ILO's Estimation, May 2017

In the South Asia, countries like Afghanistan, Bangladesh, India, Pakistan and Sri Lanka are characterized with high dependency ratio [see table IV]. This is largely due to the absence of women participation in the labor force and growing working-age population. Accordingly, in these countries, more financial stress between working people and dependents are observed. This influences the economic growth in these countries because of large amounts of dependents that pay little or no taxes. One of the notable solutions for countries with higher dependency ratio is to promote immigration for younger people. This method has particularly shown great results in Asian economies (Lain ton, 2011). However, Nepal and Maldives are in better positions bearing 0.8 and 0.94 dependency ratio respectively. This lower dependency ratio allows these two countries to adopt better pensions and health care for residents. In essence, a low-to-intermediate dependency ratio indicates that there are sufficient people in the working class who can support the dependent population (Simon et al., 2012).

\section{Unemployment}

Unemployment refers to a joblessness situation where people are actively looking for employment, but not being currently employed. Accordingly, unemployment rate is the number of unemployed people as a percentage of the labor force. Understanding unemployment scenario of an economy is essential for justifying the health of that economy. While the concept of unemployment is clear and distinct, unemployment is classified into two broad categories: voluntary and involuntary unemployment. In voluntary employment, people leave the jobs willingly in search of other employment. In contrast, in involuntary employment, workers are fired or laid off and must now look for another job.

Table 5: Unemployment Rate

\begin{tabular}{|l|r|r|r|l|r|r|r|}
\hline Country & Male & Female & Total & Country & Male & Female & Total \\
\hline Afghanistan & 12.7 & 7.7 & 8.6 & Maldives & 3.4 & 6.4 & 4.4 \\
\hline Bangladesh & 3.5 & 5.1 & 4.1 & Nepal & 3.8 & 3 & 3.4 \\
\hline Bhutan & 1.9 & 3.1 & 2.4 & Pakistan & 4.6 & 10.5 & 5.9 \\
\hline India & 3.3 & 4.1 & 3.5 & Sri Lanka & 3 & 7.5 & 4.4 \\
\hline
\end{tabular}

Source: ILO's Estimation, May 2017

As seen in table V, in Afghanistan and Pakistan, unemployment rate is comparatively higher than those of other South Asian countries. The highest unemployment rate exists in Afghanistan (8.6 per cent) followed by Pakistan (5.9 per cent) resulting in an increase in income inequality. This inequality is supposed to have a negative effect on subsequent long-run economic growth in Afghanistan and Pakistan. In addition, it also implies that human resources at a large extent remain unutilized. In contrast, the people of Nepal (3.4 per cent) and Bhutan (2.4 per cent) are less unemployed than those of Bangladesh (4.1 per cent) and India (3.5 per cent). Gender inequality also exists in this region. Females are more unemployed than those of their male counterparts in all the countries in South Asia except Afghanistan and Nepal.

\section{Time Related Underemployment}

Time related underemployment, a form of labor underutilization, exists when the employees are able and interested to do more working hours than the existing hours done in an employment (OECD, 2002). Alternatively, it denotes the number of working persons whose working hours in a reference period is not sufficient to utilize the full capacity, rather employed persons are willing and available to engage in a more desirable employment situation (ILO, 2016).

In labor studies, workers/employees that comprise the supply side of the labor market naturally match to jobs offering the number of working hours that they want (Golden and Gebrese lassie, 2007). 
Business Review- A Journal of Business Administration Discipline, Khulna University, Volume: 13, Number: 1E2,January-December 2018, pp.29-45 (Print ISSN : 1811-3788; Online ISSN : 2664-3502)

Table 6: Time-Related Underemployment Rate

\begin{tabular}{|c|c|c|c|c|c|c|c|c|c|}
\hline Country & Year & Male & Female & Total & Country & Year & Male & Female & Total \\
\hline Afghanistan & 2011 & 16.5 & 27.4 & 18.3 & Maldives* & ------ & ------ & ------ & ------ \\
\hline Bangladesh & 2016 & 2.8 & 3.4 & 3 & Nepal & 2008 & 3.7 & 3.7 & 3.7 \\
\hline Bhutan & 2010 & 3.2 & 2.4 & 2.8 & Pakistan & 2015 & 0.4 & 0.5 & 0.4 \\
\hline India* & ------ & ------ & ------ & ------ & Sri Lanka & 2014 & 2.4 & 3.2 & 2.7 \\
\hline
\end{tabular}

*Data is not available

Source: ILO's Estimation, May 2017

As per the available statistics stated in table VI, in South Asia, time related underemployment is highly present in Afghanistan (18.3 per cent) followed by Nepal (3.7 per cent) and Bangladesh (3 per cent). In addition, gender gap exists in almost all the South Asian countries to some extent. The basic implication is that this higher time-related underemployment, especially in Afghanistan, results in negative consequences on aspects such as income level, welfare dependency and life satisfaction (Wilkins, 2007). In addition, studies (e.g. Dooley et al., 2000; Fried land and Price, 2003) found that underemployment or a shift from adequately employed to time-related underemployment leads to an increase in depression, severe health and mental problems in the individuals. Pakistan is an exceptional example in this case. The underemployment rate is only 0.4 per cent in this country indicating the full utilization of workforce capacity.

\section{Not in Employment, Education or Training (NEET)}

Although the term 'NEET' was first used in a 1999 report by the Social Exclusion Unit (SEU)in UK (Robson, 2010), it has received substantive attention among the labor economists and policy makers, especially in addressing the dynamics of youth employment. NEET refers to that section of young people who are not in employment, education or training. Notably, NEET youth can be either unemployed or inactive and not involved in education or training (OECD, 2018). NEET is sometimes misunderstood with the ILO's newly coined NLFET rate. NLFET stands for "neither in the labor force nor in education or training" (ILO, 2013). The basic difference between NEET and NLFET is that NLFET excludes the unemployed youth (who are part of the labor force).

Table 7: Youth NEET Rate

\begin{tabular}{|c|c|c|c|c|c|c|c|c|c|}
\hline Country & Year & Male & Female & Total & Country & Year & Male & Female & Total \\
\hline Afghanistan* & ----- & ----- & ----- & ----- & Maldives & 2014 & 15.3 & 25.9 & 20.5 \\
\hline Bangladesh & 2016 & 10 & 47 & 28.9 & Nepal & 2008 & 22.2 & 24.4 & 23.4 \\
\hline Bhutan* & ------ & ------ & ------ & ----- & Pakistan & 2015 & 7.4 & 53.6 & 30.4 \\
\hline India & 2012 & 48 & 37.6 & 43.1 & Sri Lanka & 2014 & 17.5 & 37.3 & 27.7 \\
\hline
\end{tabular}

*Data is not available

Source: ILO's Estimation, May 2017

As noted in table VII, based on available statistics, NEET rate is comparatively higher in India (43.1 per cent) followed by Pakistan (30.4 per cent) and Bangladesh (28.9 per cent). From socio-economic perspective, the implication of a higher Youth NEET rate (as observed in India in table VII) is that it leads to multiple psychosocial risk factors (Henderson et al., 2017). Gender-based disparities also exist regarding youth NEET rate.

In Bangladesh, NEET rate among young females is 47 per cent compared to their male counterpart which is only 10 per cent. This is largely due to the fact that most of the female youths are associated with either education or reluctant to engage in employment due to social factors. Labor market conditions such as lack of suitable opportunities or qualification deficits are also vital factors behind higher NEET rate (Furlong, 2006). In essence, young people in India, Bangladesh, and Pakistan run a perceived higher risk of remaining outside the labor market in the near future (Bynner and Parsons, 2002). The case is more deteriorating in case of female youth in Bangladesh.

\section{Employment by Education, Occupation \& Sector}

Education has an important influence on labor market functioning. Education and labor market is closely related in the sense that better educated employees avails the opportunities of education premium in a labor market resulting in higher earnings and full employment (Karasiotou, 2012). In addition, several studies ( e.g., Mincer, 1958; Becker, 1964) supported the positive effect of education on lifelong labor supply/retirement decision. 
Business Review- A Journal of Business Administration Discipline, Khulna University, Volume: 13, Number: 1E2,January-December 2018, pp.29-45 (Print ISSN : 1811-3788; Online ISSN : 2664-3502)

Table 8: Employment Distribution by Education (15+)

\begin{tabular}{|c|c|c|c|c|c|c|}
\hline Country & Year & Less than basic & Basic & Intermediate & Advanced & Level not stated \\
\hline Afghanistan & --------- & -- & 5.3 & 0.2 \\
\hline Bangladesh & 2016 & ---3 & 38.2 & 14.1 & 4.3 & 7.4 \\
\hline Bhutan & 2013 & 55.5 & 17.7 & 15.2 & 9.4 & 0 \\
\hline India & 2012 & 40.1 & 42.3 & 8.2 & 2.1 & 1.3 \\
\hline Maldives & 2015 & 0.8 & 72.7 & 23.1 & 11.6 & 4.9 \\
\hline Nepal & 2008 & 49.9 & 21 & 12.6 & 7.8 & 0 \\
\hline Pakistan & 2015 & 45.4 & 28.1 & 18.8 & 18.8 & 0 \\
\hline Sri Lanka & 2014 & 16.2 & 48.9 & 16.2 & \\
\hline
\end{tabular}

Most of the labor market participants in South Asia have no basic education or are with simply basic education except Maldives. See table VIII. The case is worse in Bhutan where 55.5 per cent workers have no basic education followed by Nepal (49.9 per cent), Pakistan (45.4 percent) and Bangladesh (42.3\%). This poor level of workers' educational status affects both the supply and demand side of a labor market in this region. The workers are deprived of having good jobs with educate earnings and status, bargaining powers and so on. The employers, on the other hand, are deprived from well educated labor pool resulting in poor labor productivity. Only the workers of Nepal (11.6 per cent) and Sri Lanka (18.8 per cent) received advanced education to some extent.

Table 9: Employment by Sector

\begin{tabular}{|l|r|r|r|r|}
\hline Country & Agriculture & Industry & Services & Total \\
\hline Afghanistan & 61.6 & 10 & 28.5 & 100 \\
\hline Bangladesh & 40.6 & 19.1 & 40.3 & 100 \\
\hline Bhutan & 56.6 & 9.7 & 33.7 & 100 \\
\hline India & 43.3 & 24.5 & 32.2 & 100 \\
\hline Maldives & 7.7 & 22.8 & 69.5 & 100 \\
\hline Nepal & 72.6 & 10.9 & 16.5 & 100 \\
\hline Pakistan & 42.1 & 19.8 & 38.1 & 100 \\
\hline Sri Lanka & 27.4 & 25.9 & 46.7 & 100 \\
\hline
\end{tabular}

Source: ILO's Estimation, May 2017

Most of the workers of South Asian labor market are involved in agricultural sector except Maldives where 69.5 per cent workers are engaged in service sector. As seen in table IX, agriculture remains dominant employment sector in South Asian economies. Near about 72.6 per cent Nepalese work in agriculture sector with only 10.9 per cent in industry and 16.5 per cent in service sector. In Bangladesh, Maldives and Sri Lanka, the shift from Agriculture to service sector has been taken place at an accelerated rate since last two decades. This economic shifting is largely attributed to the impact of globalization as well as a structural transformation in the global economy since the 1950s. With the rapid development information technologies and innovations, service-oriented business has been taking the significant portion of developing economies (Victor and Fuchs, 2011). Nonetheless, labor markets in South Asia are still dominated by the agriculture.

Table 10: Employment by Occupation* (\%)

\begin{tabular}{|l|c|c|c|c|}
\hline \multicolumn{1}{|c|}{ Country } & Skill Level 1 (Low) & Skill Level 2 (Medium) & Skill Levels 3 and 4 (High) & Total \\
\hline Afghanistan & 12.9 & 83 & 4 & 100 \\
\hline Bangladesh & 16.1 & 60.5 & 23.3 & 100 \\
\hline Bhutan & 3.5 & 80 & 16.5 & 100 \\
\hline India & 26.6 & 56.6 & 16.8 & 100 \\
\hline Maldives & 10.5 & 57 & 32.5 & 100 \\
\hline Nepal & 10.6 & 84.7 & 4.7 & 100 \\
\hline Pakistan & 17.5 & 60.5 & 22 & 100 \\
\hline Sri Lanka & 20.9 & 60.4 & 18.6 & 100 \\
\hline
\end{tabular}


Business Review- A Journal of Business Administration Discipline, Khulna University, Volume: 13, Number: 1E2,January-December 2018, pp.29-45 (Print ISSN : 1811-3788; Online ISSN : 2664-3502)

* As per ISCO- 2008 Skill Groupings. (Note: Skill level 1 = Elementary Occupations; Level 2= Clerical Support, Service and Sales, Skilled Agricultural, Forestry and Fishery, Craft and Related Trade, Plant and Machine Operators and Assemblers; Level $3 \& 4=$ Technicians, Managers and Professionals.

Source: ILO's Estimation, May 2017

As seen in table $\mathrm{X}$, the labor markets of Bangladesh (23.3 per cent) and Maldives (32.5 percent) are more characterized with high skill labors (i.e., technicians, managers and professionals) than those of remaining countries in South Asia indicating a shift in economic growth. However, like other countries in South Asia, the majority of the workers of Bangladesh and Maldives fall in skill level 2. Despite an accelerated economic growth, still a significant proportion of employees are engaged in elementary occupations (skill level 1), resulting in income inequality and poor standard of living. Since jobs are becoming increasingly high tech and service-based that require different aspects of skills (Bresnahan et al., 2002), governments as well as the job providers should adopt different skill development programs.

\section{Status in Employment}

Status in employment refers to inherent characteristics of the jobs held by the employed population (ILO, 2018). Status in job is classified largely based on two criteria: type of economic risk and the type of authority over establishments and other workers which the job incumbents have or will have. Notably, own account workers and contributing family workers collectively define employment in informal sector in an economy. As stated in table XI, still most of the workers in South Asian countries are mainly own account and contributing family workers resulting in informal work arrangements and the absence of the decent work elements such as adequate social security and a voice at work. In India, for example, 65.1 per cent workers are own account workers followed by 43.9 per cent in Afghanistan and 36.2 per cent in Bangladesh and Pakistan. This implies low job security, poor earnings, and minimum collective bargaining coverage.

Table 11: Status in Employment

\begin{tabular}{|l|c|c|c|c|c|}
\hline Country & Employees & Employers & $\begin{array}{c}\text { Own-Account } \\
\text { Workers }\end{array}$ & $\begin{array}{c}\text { Contributing Family } \\
\text { Workers }\end{array}$ & Total \\
\hline Afghanistan & 27.6 & 1.1 & 43.9 & 27.3 & 100 \\
\hline Bangladesh & 44.5 & 1 & 36.2 & 18.3 & 100 \\
\hline Bhutan & 29.1 & 0.1 & 38 & 32.9 & 100 \\
\hline India & 21.2 & 1.2 & 65.1 & 12.5 & 100 \\
\hline Maldives & 75.3 & 7.4 & 15.8 & 41 & 100 \\
\hline Nepal & 22.5 & 1.4 & 35.1 & 22.8 & 100 \\
\hline Pakistan & 39.6 & 1.4 & 36.2 & 7.4 & 100 \\
\hline Sri Lanka & 57.2 & 2.8 & 32.6 & & \\
\hline
\end{tabular}

In contrast, 75.3 per cent workers are engaged in formal employment in Maldives whereas the rate is 57.2 per cent in Sri Lanka and 44.5 per cent in Bangladesh. Thus, integrating the informal economy into the formal sector is an important policy challenge for South Asian countries.

\section{Hours of Work}

Hours of work or working hours refers to the number of working hours that workers do per day, per week, per month or per year in their jobs. Working hours generally vary across regions and countries. Much of this variation occurs due to part-time work arrangements and patterns of female labor market participation (Dolton, 2017). In labor economics, the practice of working hours in critically important as it largely affects the labor productivity as well as the workers' work-life balance consideration. Several studies were conducted so far examining the impact of working hours on productivity (Faggio and Nickell, 2007). In a study, White and Ghobadian (1984) found that a shorter working hours lead to working time flexibility and substantial productivity gains. However, due to the shorter and flexible working hours, 'output rises linearly with hours up to a threshold, but above this, output rises at a decreasing rate' (Pencavel, 2015). 
Business Review- A Journal of Business Administration Discipline, Khulna University, Volume: 13, Number: 1E2,January-December 2018, pp.29-45 (Print ISSN : 1811-3788; Online ISSN : 2664-3502)

Table 12: Hours of Work

\begin{tabular}{|l|c|c|c|c|c|}
\hline \multicolumn{1}{|c|}{ Country } & Year & $\begin{array}{c}\text { Mean weekly hours } \\
\text { actually worked per } \\
\text { employed person }\end{array}$ & Country & Year & $\begin{array}{c}\text { Mean weekly hours } \\
\text { actually worked per } \\
\text { employed person }\end{array}$ \\
\hline Afghanistan* & ------ & ---------- & Maldives & 2014 & 41 \\
\hline Bangladesh & 2016 & 49 & Nepal & 2015 & 54 \\
\hline Bhutan* & ------ & ---------- & Pakistan & 2016 & 47 \\
\hline India* & ------ & ---------- & Sri Lanka & 2014 & 42 \\
\hline
\end{tabular}

*Data is not available

Source: ILO, 2018

As noted in table XII, the mean weekly working hours differ among South Asian countries to some extent. Nepalese workers work near about 54 hours per week followed by 49 hours by Bangladeshi workers. Notably, south Asian workers work more than 40 hours a week on an average. Although table XII indicates 49 working hours per week in case of Bangladesh, a recent report of ILO has indicated that more than 58.8 per cent Bangladeshi employees work more than 48 hours a week. This excessive working time results in work-life imbalance, fatigue, poor productivity, social disorders, and so on.

Workers mainly tend to work more working hours in these countries, especially in Bangladesh and Nepal, due to budget constraints to support the personal and family life. Moreover, within-skill wage inequality (i.e. wage gap between workers of same skill-level) gives incentives to work longer hours to some extent (Michelacci et al., 2008).

\section{Wage and Wage Growth}

Earnings from employment, generally in form of wages, are the monetary compensation that workers receive from the jobs that they hold. The understandings of wage and wage growth in a particular economy are essential to explore the living standards of workers as well as their bargaining power in the labor market. Out of many reasons, people mainly do the work for adequate earnings to support their livings and desires. Like working hours, wage differences are evident across countries and regions. Even in market economy where the wage is set by demandsupply pattern of labor, there are evidences that wage differences are prevalent in many countries based on sex, age and race (Magnusson, 2015). In addition to market forces (demand and supply), structures and traditions of the economy exert significant influence on wage-setting.

Table 13: Average Monthly Earnings

\begin{tabular}{|l|r|r|r|r|}
\hline Country & Year & Local Currency & Constant 2011 PPP \$ & U. S. Dollars \\
\hline Afghanistan* & ------ & ----- & ----- & ----- \\
\hline Bangladesh & 2016 & 12915 & 435 & 165 \\
\hline Bhutan* & ----- & ------ & ----- & ------ \\
\hline India* & ------ & 1034 & ----- \\
\hline Maldives & 2010 & ----- & 411 & 635 \\
\hline Nepal & 2008 & 8132 & 511 & 102 \\
\hline Pakistan & 2016 & 7125 & 366 & 142 \\
\hline Sri Lanka & 2010 & 14921 & 13900 & 123 \\
\hline
\end{tabular}

*Data is not available

Source: ILO's Estimation, May 2017

Being a tropical country with separated islands, Maldives is far ahead of other countries in this region in terms of income from employment. The average monthly income of the workers in this country is 635 US\$ [see table XIII]. The second highest average monthly income is enjoyed by Bangladeshi workers (165 US\$). However, this average monthly wage is insufficient to support the living expenses considering the price hike and house rents. The case is more severe in other countries like Nepal and Sri Lanka where average monthly income is 102 US\$ and 123 US\$ respectively. The poor monthly income substantively influences the labor market outcomes, poverty levels and the government accounts (Foguel et al., 2001). 
Business Review- A Journal of Business Administration Discipline, Khulna University, Volume: 13, Number: 1E2,January-December 2018, pp.29-45 (Print ISSN : 1811-3788; Online ISSN : 2664-3502)

Table 14: Wage Growth Rate

\begin{tabular}{|l|c|c|c|c|c|}
\hline \multicolumn{1}{|c|}{ Country } & Year & Annual Growth $(\%)$ & Country & Year & Annual Growth $(\%)$ \\
\hline Afghanistan* & ---- & ----- & Maldives* & ---- & ------ \\
\hline Bangladesh & 2015 & 2.4 & Nepal & 2015 & -0.3 \\
\hline Bhutan* & ---- & ----- & Pakistan & 2015 & 8.9 \\
\hline India & 2012 & 1 & Sri Lanka & 2012 & -3.3 \\
\hline
\end{tabular}

*Data is not available

Source: ILO's Estimation, December 2016

In addition to poor monthly average income, South Asian labor economies are characterized with sluggish wage growth. Even in countries like Nepal and Sri Lanka, based on the available statistics as presented in table XIV, the growth rate is negative. The annual wage growth rate is 2.4 per cent in Bangladesh indicating a low-to-moderate bargaining power of workers and workers' associations. Moreover, the 7.3 per cent GDP growth rate (2017) is also positively contributing to wage increase. Nonetheless, still the minimum wage in this growing economy is 5300 Taka (equivalent to 63 US\$). In essence, the negative and the slow wage growth in South Asia is not commensurate to the inflation that ultimately results in poor labor productivity. Thus, aggregate demand/aggregate supply and macroeconomic factors are adversely affected to a large extent.

\section{Labor Productivity}

Labor productivity, also termed as workforce productivity, refers to real economic output per labor hour. Alternatively, labor productivity is a measure of the hourly output of a country's economy. Growth in labor productivity is calculated by the change in economic output per labor hour over a defined period. Notably, labor productivity should not be confused with the term 'employee productivity' which implies an individual worker's output. Labor productivity in an economy is largely influenced by at least three factors: investment and saving in physical capital, new technology and human capital.

Table 15: Labor Productivity

\begin{tabular}{|l|c|c|}
\hline Country & $\begin{array}{c}\text { Output Per Worker (GDP Constant 2005 US } \\
\$ \text { ) }\end{array}$ & $\begin{array}{c}\text { Output Per Worker (GDP Constant 2011 } \\
\text { International \$ in PPP) }\end{array}$ \\
\hline Afghanistan & 2188 & 6383 \\
\hline Bangladesh & 2543 & 8197 \\
\hline Bhutan & 6000 & 17678 \\
\hline India & 5240 & 17150 \\
\hline Maldives & 13744 & 22826 \\
\hline Nepal & 1281 & 4295 \\
\hline Pakistan & 3617 & 14896 \\
\hline Sri Lanka & 10667 & 32397 \\
\hline
\end{tabular}

As seen in table $\mathrm{XV}$, the economy of Maldives and Sri Lanka are credited with higher labor productivity $(22,826$ and 32,397 output per worker consecutively) than those of other countries in South Asia resulting in an improved standards of living in the form of higher consumption. This in turn increases the cycle of production for goods and services. The output per worker in Bangladesh is only 8,197 as per 2011 PPP which is apparently at the bottom of the list except Nepal and Afghanistan. This poor labor productivity in Afghanistan, Bangladesh and Nepal indicates the poor skilled labor force in terms of education, experience and expertise.

\section{Working Poor}

Working poor refers to that section of the workers whose wages fall below a given poverty line. This is largely occurred due to the lack of adequate working hours or poor wages. Whatever the cause is, working poor makes it difficult for the workers to maintain a standard life with a sense of self-worth (Ehrenreich, 2001). Thus, the existence of working poor in a labor market often attributes the prevalence of inequality. 
Business Review- A Journal of Business Administration Discipline, Khulna University, Volume: 13, Number: 1E2,January-December 2018, pp.29-45 (Print ISSN : 1811-3788; Online ISSN : 2664-3502)

Table 16: Employment by Economic Class (15+) (\%)

\begin{tabular}{|l|c|c|c|c|}
\hline \multicolumn{1}{|c|}{ Country } & $\begin{array}{c}\text { Extremely poor } \\
(<\mathrm{US} \$ 1.90, \mathrm{PPP})\end{array}$ & $\begin{array}{c}\text { Moderately poor (>=US\$1.90 } \\
\&<\mathrm{US} \$ 3.10, \mathrm{PPP})\end{array}$ & $\begin{array}{c}\text { Near poor }(>=\mathrm{US} \$ 3.10 \\
\&<\mathrm{US} \$ 5, \mathrm{PPP})\end{array}$ & Total \\
\hline Afghanistan & 82.8 & 4.2 & 5.5 & 100 \\
\hline Bangladesh & 61.1 & 22.1 & 9.6 & 100 \\
\hline Bhutan & 3.8 & 4.4 & 31.2 & 100 \\
\hline India & 11.2 & 36.4 & 16.7 & 100 \\
\hline Maldives & 5.8 & 5.5 & 40.7 & 100 \\
\hline Nepal & 7.2 & 24.7 & 43.6 & 100 \\
\hline Pakistan & 7.5 & 26.6 & 18.3 & 100 \\
\hline Sri Lanka & 3.9 & 6.8 & & \\
\hline
\end{tabular}

As noted in table XVI, Afghan workers (82.8 per cent) are largely subjected to extremely poor income $(<$ US $\$ 1.90$, PPP) followed by 61.1 per cent Bangladeshi workers resulting in poor living standards and income inequality. The case is reverse in case of Bhutan, Maldives and Sri Lanka where only 3.8, 5.8, and 3.9 percent workers lead the life with 'extremely poor' income. Working poor remains at moderate level in India, Nepal and Pakistan. However, working poor differs in terms of sect oral, demographic and occupational differences in an economy.

\section{Labor Market Projections}

This section is concluded with the brief description of ILO's labor projection to 2020 for South Asian labor market. This projection is supposed to better inform employers (demand side of labor market), policy makers, labor economists, researchers and the other stakeholders to a large extent in crafting a picture of labor market in near future. In addition, this projected labor statistics can be used to analyze potential future imbalances in the labor market.

Table 17: Labor Market Projections (15+) (2020)

\begin{tabular}{lccc}
\hline Country & $\begin{array}{c}\text { Labor Force Participation } \\
\text { Rate }\end{array}$ & $\begin{array}{c}\text { Employment-to- } \\
\text { Population Ratio }\end{array}$ & Unemployment Rate \\
\hline Afghanistan & 52.6 & 48.2 & 8.5 \\
Bangladesh & 62.3 & 59.9 & 4 \\
Bhutan & 67.9 & 66.2 & 2.5 \\
India & 53.9 & 52 & 3.6 \\
Maldives & 70.8 & 68.5 & 3.3 \\
Nepal & 83.3 & 80.7 & 3.1 \\
Pakistan & 54.8 & 51.6 & 5.9 \\
Sri Lanka & 51 & 48.4 & 5 \\
\hline
\end{tabular}

Unemployment rate is supposed to remain at an alarming rate in Afghanistan (8.5 per cent) and Pakistan (5.9 per cent) in 2020 [see table XVII]. Although the existing unemployment rate is 4.1 per cent (2017) in Bangladesh, the rate is expected to slightly decline to 4 per cent in 2020. However, the labor force participation rate is projected to reach at 62.3 per cent in 2020 which was 56.5 per cent in 2017. Almost all the South Asian countries are expected to experience increased labor force participation and higher employment-to-population ratio in coming years indicating a bright potential for both labor market functioning and the economic growth.

\section{Key Findings and Policy Responses}

Despite historical, geo-political and ethnical differences between South Asian countries, the labor market dynamics are homogeneous to a large extent. This fastest growing economic region with an estimated 7.0 percent growth rate in 2019 exerts significant potentials for labor market development. Nonetheless, the labor economies of this region are confronted with multiple challenges raising the question of utilizing 'human capital' at the maximum level. Several policies, both short-term and long-term, are deemed to be adopted at both regional (SAARC) and national 
Business Review- A Journal of Business Administration Discipline, Khulna University, Volume: 13, Number: 1E2,January-December 2018, pp.29-45 (Print ISSN : 1811-3788; Online ISSN : 2664-3502)

level in order to avail the advantage of 'demographic dividend'. This will ultimately turn into an opportunity to drive economic expansion and increase gross domestic product in this region.

As noted earlier, South Asia is blessed with near about 40 per cent working-age population (15-64 years). Considering the whole world, the potential labor force in developing countries is projected to increase by 39 per cent on an average in the coming 40 years (World watch, 2018). Fortunately, a quarter of this potential labor force lives in South Asia. This indicates the enormous potential for abundant labor pool for driving the wheels of South Asian economy. Nonetheless, the labor force participation rate considerably remains low. The women's involvement in employment is very negligible as compared to their male counterparts. Expanding the existing labor market to create more jobs for this growing workforce is a challenge for South Asian policy makers.

Since labor force participation indicates the health of the labor market and it varies with demographic factors such as gender, age, education, marital status, and childcare provisions, policymakers must need to take several options into considerations. Encouraging private sector investment is a good option in this case, especially in creating more jobs for the new entrants. Several structural changes in the labor market are required to be made including the aging of the workforce. Fiscal and monetary policies focusing on strengthening economic growth and prioritizing full employment are supposed to boost labor force participation rate. Reducing discriminatory employment practices (e.g., age, sex, and region) can bring positive result in this regard. In an objective to increase female participation in labor market, several policy reforms are needed such as flexible working-time arrangements, childcare, maternity leave and benefits, and adequate education and training facilities for skill development.

The unemployment rates in South Asian countries are apparently low because remaining unemployed is difficult due to the lack of social support to the unemployed people. Moreover, the hardship of economic conditions makes the people bound to work. However, female women employment rate is still high at Afghanistan, Maldives and Pakistan. This is largely due to social outlook towards female employment. Several policies like skill development programs, increasing the occupational and geographical labor mobility, and encouraging entrepreneurship are supposed to reduce the unemployment to a minimum level. Labor underutilization, mainly time-related underemployment, is a notable feature of South Asian labor market indicating that labor resources are not being fully utilized. This poses a serious economic problem at both macro and firm level exerting critical implications for understanding (effective) labor supply. Time related underemployment is frequently observed among new entrants, females and part-time workers. However, from policy perspective, policies for boosting employment and lowering unemployment are also expected to lower time related underemployment.

Another challenging issue for South Asian labor market is the increasing youth NEET rate, especially the female section of the society. Near about 47 per cent young females in Bangladesh are in not in education, employment, or training (NEET). The case is almost similar to other countries in this region. Studies support the detrimental effect of time spent NEET on physical and mental health and the increase likelihood of unemployment, working poor, or poor labor productivity in later period of life (PHE, 2014). Encouraging young people to participate in education and training programs, introducing apprenticeships and traineeships programs, reforming technical education, providing career advice and financial assistance can bring better results in reducing youth NEET rate.

Labor dependency ratio is comparatively higher in Afghanistan and Pakistan creating pressure to productive population in these two countries. In long-term, this high dependency ratio may lower economic growth. Policies aiming at increasing productivity, promoting immigration for younger people, increasing the labor force participation of the elderly, encouraging women employment, and creating part-time job facilities for young and running students are supposed to lower the dependency ratio.

Most of workers in South Asia are with less than basic education that exerts significant impact on their skill level. As presented in table $\mathrm{X}$ in this paper, the major proportion of workers is engaged in employments featured with skill level 1 and 2. This poor skill in turn results in poor labor productivity leading to working poor to a large extent. Introducing vocational education at the high-school level, setting training institute at the district or sub-district level, arranging separate training programs for women, encouraging technical education, providing incentives to training and skill development institutes, and addressing the need of projected labor market demand are likely to be quite useful for enhancing skill level resulting in high labor productivity and adequate earnings from employment. 
Business Review- A Journal of Business Administration Discipline, Khulna University, Volume: 13, Number: 1E2,January-December 2018, pp.29-45 (Print ISSN : 1811-3788; Online ISSN : 2664-3502)

Informal employment makes up a significant portion of South Asian labor market economies. Since employment in the informal sectors are largely attributed to poor and unstable income, less job security and less access to basic protections and services (Beneria and Floro, 2006), policy makers must find out the ways how the informal economy can be integrated into the formal sector. The South Asian governments should realize 'the value and importance of the informal sector, regulate and restrict when necessary but generally work to improve working conditions and increase efficiency and production' (Becker, 2004).

\section{Conclusion}

South Asia is one of the fastest growing economic regions in the world. The trends of declining fertility rates and improved life expectancy cause significant growth in population which is projected to increase to 2.4 billion by 2050. Moreover, this region is blessed with 40 per cent of world's working-age population exerting significant potential for availing 'demographic dividend' opportunities. With an increasing GDP growth rate since last two decades, South Asia has the potential to absorb labor at a large scale in coming years. Despite ethnical, geo-political and religious differences between countries, the labor market patterns are homogenous to a large extent in this southern region of the Asian continent. Labor economies, although vary to a large extent in some cases, of this region are characterized with low labor force participation rate, gender disparity in employment, working poor, high labor dependency ration, slow wage growth, high NEET rate, excessive working hours, shortage of skill, poor labor productivity and dominance of informal sector in employment. However, South Asia is apparently yet to adopt timeworthy policies to fully capitalize on the demographic dividend.

Several economic, education and labor policies are deemed to be useful for a better South Asian labor market like emphasizing on vocational education, setting training institutions, inclusion of maximum people including women and youths in training and skill development programs, reviewing the national wage policy on a regular basis, ensuring maternity and childcare facilities, encouraging apprenticeship, providing incentives for technical education, revising labor policies, and updating the migration policies. Whatever the policy is, demographic dividend is such a vital window of opportunity that the South Asian countries should not miss. The countries of this fastest growing economic region must prepare themselves for demographic transition that will follow in next few decades. Several areas of South Asian labor market, at both regional and country level, are needed to be explored through future studies.

\section{References}

Alli, B. (2009), Fundamental Principles of Health and Safety at Work, ILO, Geneva.

Becker, G. (1964), Human capital: A theoretical and empirical analysis with special reference to education, University of Chicago Press, Chicago.

Becker, F. K. (2004), The Informal Economy: Fact Finding Study, Sida, Stockholm.

Beneria, L. and Floro, S. M. (2006), Labor Market Informalization, Gender and Social Protection: Reflections on Poor Urban Households in Bolivia, Ecuador and Thailand, Palgrave Macmillan, New York.

Bowen, G. A. (2009), "Document analysis as a qualitative research method", Qualitative Research Journal, Vol. 9, No. 2, pp. 27-40.

Bresnahan, T. F., Brynjolfsson, E. and Hitt, L. M. (2002), "Information technology, workplace organization, and the demand for skilled labor: Firm-level evidence. The Quarterly Journal of Economics, Vol. 117, No. 1, pp. 339-376.

Burchell, B., Sehnbruch, K., Piasna, A. andAgloni, N. (2014), "The quality of employment and decent work: Definitions, methodologies, and ongoing debates", Cambridge Journal of Economics, Vol. 38, pp. 459477.

Bynner, J. and Parsons, S. (2002), "Social exclusion and the transition from school to work: The case of young people not in education, employment or training", Journal of Vocational Behavior, Vol. 60, No. 2, pp. 289309.

Chamberlin, G. (2011), “Okun's law revisited”, Economic \& Labour Market Review, Vol. 5, No. 2,pp. $104-132$.

Chand, M. (2018), "Aging in South Asia: Challenges and opportunities", South Asian Journal of Business Studies, Vol. 7, No. 2, pp. 189-206. 
Business Review- A Journal of Business Administration Discipline, Khulna University, Volume: 13, Number: 1E2,January-December 2018, pp.29-45 (Print ISSN : 1811-3788; Online ISSN : 2664-3502)

Daly, C. M., Fernald, G. H., Jordà, O. and Nechio, F. (2014), Labor Markets in the Global Financial Crisis: The Good, the Bad and the Ugly, Federal Reserve Bank of San Francisco, San Francisco.

Dex, S. and Bond, S. (2005), "Measuring work-life balance and its covariates", Work, Employment \& Society, Vol. 19 , No. 3, pp. 627-637

Doherty, M., Leung, B., Lorenze, K. and Wilmarth, A. (2014), Understanding South Asian Labor Migration, La Follette School of Public Affairs, Madison.

Dolton, P. (2017), Working Hours: Past, Present, and Future, IZA World of Labor, Bonn.

Dooley, D., Prause, J. and Ham-Rowbottom, K. A. (2000), "Underemployment and depression: Longitudinal relationships", Journal of Health and Social Behavior, Vol. 41, pp. 421-436.

Ehrenreich, B. (2001),Nickel and Dimed: On (Not) Getting By in America, Holt Paperbacks, New York.

Faggio, G. and Nickell, S. (2007), "Patterns of work across the OECD", The Economic Journal,Vol. 117, No. 521, pp. F416-F440.

Foguel, M. N., Ramos, A., Roberto, L. and Carneiro, F. G. (2001), The Impact of the Minimum Wage on the Labor Market, Poverty and Fiscal Budget in Brazil, IPEA, Brazil.

Friedland, D. S. and Price, R. H. (2003), "Underemployment: Consequences for the Health and Well-Being of Workers", American Journal of Community Psychology, Vol. 32, pp. 33-45.

Furlong, A. (2006), "Not a very NEET solution: Representing problematic labour market transitions among early school leavers", Work, Employment and Society, Vol. 20, No. 3, pp. 553-569.

Gallie, D., Felstead, A. and Green, F. (2004), "Changing patterns of task discretion in Britain”, Work Employment Society, Vol. 18, No. 2, pp. 243-266.

Gallie, D. (2007), "Production regimes and the quality of employment in Europe", Annual Review of Sociology, Vol. 33, No. 1, pp. 85-104.

Golden, L. and Wiens-Tuers, B. (2008), "Overtime work and wellbeing at home", Review of Social Economy, Vol. 66, pp. 25-29.

Gros, D. and Alcidi, C. (2010), "The impact of the financial crisis on the real Economy", Intereconomics, Vol. 45, No. 1, pp. 4-20.

Hall, P. A. and Soskice, D. (2001), Varieties of Capitalism, Oxford University Press, Oxford.

Henderson, L. J., Hawkea, D. L. and Chaim, G. (2017), "Not in employment, education or training: Mental health, substance use, and disengagement in a multi-sectoral sample of service-seeking", Canadian Youth, Children and Youth Services Review, Vol. 75, pp. 138-145.

Herwartz, H. and Niebuhr, A. (2011), "Growth, unemployment and labour institutions: Evidence from a crosssection of EU Regions", Applied Economics, Vol. 43, pp. 4663-4676.

IMF. (2018), South Asia: The Robust Outlook Continues, IMF, Washington, DC.

ILO.(1998), Resolution Concerning the Measurement of Underemployment and Inadequate Employment Situations, ILO, Geneva.

ILO. (2013), Global Employment Trends for Youth, ILO, Geneva.

ILO.(2015), Key Indicators of the Labour Market (KILM), ILO, Geneva.

ILO.(2016), Key Indicators of the Labour Market, ILO, Geneva.

ILO.(2018), World Employment Social Outlook Trends, ILO, Geneva.

ILO.(2019), Employment, International Labour Organization, Geneva.

Kalleberg, A. L. (2011), The Rise of Polarized and Precarious Employment Systems in the United States, 1970s to 2000 s, Russell Sage Foundation, New York.

Kim, C. and Bhardwaj, G. (2011), South Asia Pension Forum: Fostering Inclusive and Sustainable Pension Systems in the Region, ADB, Manila.

Lainton, A. (2011), Dependency Ratio and Immigration/Emigration[Online].Available from https://andrewlainton.wordpress.com/dependency-ratio-and-immigration [Accessed 23rd October 2018]

Lee, J. (2000), “The robustness of okun's law: Evidence from OECD countries", Journal of Macroeconomics, Vol. 22 , No. 2, pp. 331-356.

Leschke, J. and Watt, A. (2010), Labour Market Impacts of the Global Economic Crisis and Policy Responses in Europe, European Trade Union Institute, Brussels.

Magnusson, C. (2015), Why is there a Gender Wage Gap according to Occupational Prestige? Sage, London. 
Business Review- A Journal of Business Administration Discipline, Khulna University, Volume: 13, Number: 1E2,January-December 2018, pp.29-45 (Print ISSN : 1811-3788; Online ISSN : 2664-3502)

Mann, M. (2014), South Asia's Modern History: Thematic Perspectives, Taylor \& Francis, UK.

Mincer, G. (1958), "Investment in human capital and personal income distribution", Journal of Political Economy, Vol. 66, pp. 281-302.

Michelacci, C. and Pijoan-Mas, J. (2008), The Effects of Labor Market Conditions on Working Time: the US-EU Experience, Rimini Centre for Economic Analysis, Ontario.

Moazzami, B. and Dadgostar, B. (2009), "Okun's law revisited: Evidence from OECD countries", International Business \& Economics Research Journal, Vol. 8, No. 8, pp. 21-24.

Niebuhr, A. (2003), "Spatial interaction and regional unemployment in Europe", European Journal of Spatial Development, No. 5, pp. 1-26.

Oberst, C. A. (2012), A Methodology Approach to Delineate Functional Economic Market Areas with an Iterative Three-Step Spatial Clustering Procedure, CAWM, Tanzania.

OECD. (2002), OECD Glossary of Statistical Terms - Time Related Underemployment, Organization for Economic Co-operation and Development, Paris.

OECD.(2018), LFS by Sex and Age - Indicators, OECD, Paris.

O’Leary, Z. (2014), The Essential Guide to Doing Your Research Project, Sage, Thousand Oaks, CA.

Pencavel, J. (2015), "The productivity of working hours', The Economic Journal, Vol. 125, No. 589, pp. 2052-2076.

PHE. (2014), Local Action on Health Inequalities: Reducing the Number of Young People Not in Employment, Education or Training (NEET), Public Health England, London.

Prior, L. (2003), Using Documents in Social Research, Sage, London.

Ramaswamy, V. K. (2003), Globalization and Industrial Labor Markets in South Asia: Some Aspects of Adjustment in a Less Integrated Region, East-West Center, Hawaii.

Razzaque, J. (2004), Public Interest Environmental Litigation in India, Pakistan, and Bangladesh, Kluwer Law International, Netherlands.

Reinecke, G. and White, S. (2004), Policies for Small Enterprises: Creating the Right Environment for Good Jobs, ILO, Geneva.

Robson, K. (2010), Growing Gaps: Educational Inequality around the World, Oxford University Press, Oxford.

Rose, M. (2003), Good Deal, Bad Deal? Work Employment Society, Vol. 17, No. 3, pp. 503-530

Scott, J. (2006), Documentary Research, Sage, London.

Seth , S. (2018) South Asia: The New Face of Emerging Economies [Online]. Available from:https://www.investopedia.com/articles/investing/022316[Accessed 23rd October 2018]

Shamsuddin, M. (2013), Three Essays on Labor Markets of South Asian Countries, Georgetown University, Washington DC.

Sharma,N. A. (2017), South Asian Labour and Employment Report: Promoting Inclusive Growth, Institute for Human Development, New Delhi.

Sharma, N. A. (2018), Employment Challenge in South Asia, Institute for Human Development, Delhi.

Simon, C., Belyakov, A. O. and Feichtinger, G. (2012), "Minimizing the dependency ratio in a population with below-replacement fertility through immigration", Theoretical Population Biology, Vol. 82, No. (3), pp. 158-69.

Srivastava, R. and Pande, K. A. (2017), Internal and International Migration in South Asia: Drivers, Interlinkage and Policy Issues, UNESCO, New Delhi.

Victor, R, F. (2011), Who Shall Live? Health, Economics and Social Choice, World Scientific, London.

White, M. and Ghobadian, A. (1984), Shorter Working Hours in Practice, Policy Studies Institute, London.

Wilkins, R. (2007), "The consequences of underemployment for the underemployed", Journal of Industrial Relations, Vol. 49, pp. 247-275.

World Bank.(2011), South Asia Development Matters, World Bank, Washington DC.

World Bank. (2011), More and Better Jobs in South Asia, World Bank, Washington DC.

World Bank.(2019), South Asia, World Bank, Washington DC.

World Bank. (2018), The World Bank in Afghanistan, World Bank, Washington DC.

World Watch. (2018), Increase in the Labor Force Can Be an Engine for Development, World watch Institute, Washington DC. 